\title{
Skrining Fitokimia dan Uji Daya Hambat Ektrak Daun Jahe Merah (Zingiber officinale var rubrum) Terhadap Bakteri Staphylococcus Epidermidis dan Escherichia Coli
}

\author{
Annisa Humairah Ibrahim. ${ }^{1}$, Hamisidar Hasan ${ }^{2}$, Mahdalena Sy. Pakaya ${ }^{3}$ \\ 1,2,3 Jurusan Farmasi, Fakultas Olahraga dan Kesehatan, Universitas Negeri Gorontalo, Gorontalo \\ *E-mail: annisaibrahim04@gmail.com
}

\begin{tabular}{l} 
Article Info: \\
Received: 24 April 2021 \\
in revised form: 28 Mei 2021 \\
Accepted: 30Mei 2021 \\
Available Online: 30 Mei 2021 \\
\hline Keywords: \\
Red Ginger Leaves \\
Staphylococcus epidermidis \\
Escherichia coli \\
Inhibition \\
\hline Corresponding Author: \\
Annisa Humairah \\
Ibrahim \\
Jurusan Farmasi \\
Fakultas Olahraga dan \\
Kesehatan \\
Universitas Negeri Gorontalo \\
E-mail: \\
annisaibrahim04@gmail.com
\end{tabular}

\section{ABSTRACT}

Infectious disease is one of the diseases caused by microbes, including bacteria. Staphylococcus epidermidis and Escherichia coli are gram-positive and gram-negative bacteria that cause infectious diseases. The selection of medicinal plants as an alternative solution is an effective way of reducing the resistance of bacteria. Based on the empirical data, herbal plants with antimicrobial potential are red ginger (Zingiber officinale var rubrum). This research aimed to determine the inhibition test on Staphylococcus Epidermidis and Escherichia coli due to phytochemical compounds contained in the leaves of red ginger which serve as an antibacterial. Through this experimental laboratory research, a crude drug was extracted using n-hexane, chloroform, ethyl acetate, and methanol solvent. The phytochemical screening results of n-hexane extract showed that red ginger leaves contain alkaloids and terpenoids; chloroform extract contains alkaloids, steroids, and tannins; ethyl acetate extract contains alkaloids, steroids, flavonoids, and tannins; and the methanol extract contains alkaloids, terpenoids, flavonoids, and tannins. Chloramphenicol and Dimethyl sulfoxide (DMSO) were used as the positive control and negative control respectively. Inhibition test results were obtained from the four n-hexane extracts, chloroform extracts, ethyl acetate extracts, and methanol extracts with three different concentrations.The results obtained the greatest inhibition against Staphylococcus Epidermidis bacteria, namely at a concentration of $20 \%$ chlorform extract of red ginger leaves as large as $18,90 \mathrm{~mm}$. Meanwhile, the inhibition of Escherichia Coli is at a concentration of $20 \%$ n-hexane extract with an inhibitory power of $17,84 \mathrm{~mm}$ inhibition zone that is classified as a strong category to inhibit the growth of bacteria. The results of the One Way ANOVA data analysis ( $p<0.01$ ) with a confidence level of $99 \%$. 
This open access article is distributed under a Creative Commons Attribution (CC-BY-NC-SA) 4.0 International license.

How to cite (APA $6^{\text {th }}$ Style):

Ibrahim.A.H.,Hasan.H.,Pakaya.M.Sy.(2021). Skrining fitokimia dan uji daya hambat ektrak daun jahe merah (zingiber officinale var rubrum) terhadap bakteri staphylococcus epidermidis dan escherichia coli. Indonesian Journal of Pharmaceutical (eJournal),1(3), 107-119.

\section{ABSTRAK}

Penyakit infeksi merupakan salah satu penyakit yang disebabkan oleh mikroba diantaranya bakteri. Staphylococcus epidermidis dan Escherichia coli merupakan bakteri Gram positif dan negatif sebagai penyebab penyakit infeksi. Pemilihan Tanaman obat sebagai alternatif merupakan cara yang efektif dalam mengurangi resistensi bakteri. Berdasarkan data empiris, tanaman herbal yang memiliki potensi sebagai antimikroba yaitu Jahe merah (Zingiber officinale var rubrum). penelitian yang bertujuan untuk mengetahui uji Daya hambat terhadap bakteri Staphylococcus Epidermidis dan Escherchia coli karena mengingat senyawa fitokimia yang terkandung dalam daun jahe merah (Zingiber officinale var rubrum) dapat bermanfaat sebagai antibakteri. Penelitian ini merupakan penelitian eksperimental laboratorium. Simplisia diekstraksi menggunakan pelarut n-heksan, kloroform, etil asetat dan metanol. Hasil skrining fitokimia ekstrak n-heksan daun jahe merah mengandung alkaloid dan terpenoid, ekstrak kloroform mengandung alkaloid, steroid dan tanin, ekstrak etil asetat mengandung alkaloid, steroid, flavonoid dan tanin, dan pada ekstrak metanol mengandung alkaloid, terpenoid, flavonoid dan tanin. Kontrol positif yang digunakan yaitu kloramfenikol dan kontrol negatif digunakan Dimetil sulfoksida (DMSO). Hasil uji daya hambat didapatkan dari keempat ekstrak n-heksan, ekstrak kloroform, ekstrak etil asetat, dan ekstrak metanol dengan tiga konsentrasi yang berbeda di dapatkan hasil daya hambat yang paling besar terhadap bakteri Staphylococcus Epidermidis yaitu pada konsentrasi 20\% ekstrak klorform daun jahe merah sebesar 18,90 mm. Sedangkan untuk daya hambat terhadap Escherichia Coli yaitu pada konsentrasi $20 \%$ esktrak n-heksan dengan daya hambat sebesar 17,84 mm dimana zona hambat ini termasuk dalam kategori kuat untuk menghambat pertumbuhan bakteri. Hasil analisis data One Way ANOVA $(\mathrm{p}<0,01)$ dengan tingkat kepercayaan 99\%.

Kata Kunci: Daun Jahe merah ,Staphylococcus epidermidis, Escherichia coli, Daya hambat.

\section{Pendahuluan}

Bakteri patogen dapat menyebar melalui populasi manusia dalam berbagai cara. Bakteri patogen yang menyebabkan Penyakit infeksi diantaranya terdapat bakteri gram positif salah satunya yaitu Staphylococcus epidermidis dan bakteri gram negative salah satu bakterinya yaitu Escherichia coli.Pengobatan infeksi yang disebabkan bakteri patogen melibatkan penggunaan antibiotik, namun karena meningkatnya resistensi bakteri terhadap berbagai jenis antibiotik hingga akhirnya penggunaan antibiotik menjadi tidak efektif [4].

Bahan alam dapat dimanfaatkan sebagai obat tradisional yang menjadi salah satu upaya dalam penanggulangan masalah kesehatan yang dihadapi.Kemajuan teknologi dan ilmu pengetahuan modern yang semakin pesat dan canggih di zaman sekarang ini, ternyata tidak mampu menggeser atau mengesampingkan begitu saja obat tradisional.Hal ini terbukti dari banyaknya masyarakat yang masih menggunakan bahan alam sebagai pengobatan tradisional.Tanaman yang berasal dari bahan alam atau sebagai tanaman herbal dapat dikembangkan untuk mengatasi berbagai penyakit infeksi yang disebabkan oleh mikroba, karena didalam tanaman herbal tersebut memiliki kandungan senyawa bioaktif [2]. 
Salah satu bahan alam yang sering digunakan sebagai obat herbal yaitu Jahe merah (Zingiber officinale var rubrum). Tanaman jahe diketahui memiliki komposisi bahan aktif fitokimia berupa oleoresin terutama gingerols, shagols sesquiterpen ( $\beta$-bisabolen) dan monoterpen (geranial dan neral). Pada Rimpang jahe merah mengandung senyawa antimikroba golongan fenol, flavonoid, terpenoid dan minyak atsiri senyawa tersebut merupakan golongan senyawa bioaktif yang dapat menghambat pertumbuhan mikroba dan dapat dijadikan sebagai antibakteri [5][16].Selain dari rimpang jahe bagian dari Daun jahe merah mengandung senyawa antioksidan berfungsi juga sebagai antimikroba. Ekstrak daun jahe merah mengandung senyawa monoterpenoid, sekuiterpenoid, alkaloid, flavonoid, fenol yang dapat dikategorikan senyawa antioksidan dan antibakteri[1][6].

Penggunaan ekstrak Zingiber officinale var. rubrum untuk mengatasi reumatik, osteoporosis, asma, batukmdan tumor [9].Ekstrak jahe (Zingiber Officinale) mempunyai kemampuan untuk menghambat pertumbuhan bakteri. Untuk dapat menarik senyawa metabolit sekunder pada tanaman tersebut dilakukan ekstraksi dengan cara maserasi menggunakan beberapa pelarut organik [16].

Berdasarkan uraian diatas, akan dilakukan penelitian yang bertujuan untuk mengetahui uji daya hambat terhadap bakteri penyebab infeksi yaitu bakteri staphylococcus Epidermidis dan Escherchia coli karena mengingat senyawa fitokimia yang terkandung dalam jahe merah (Zingiber officinale var rubrum) dapat bermanfaat sebagai antibakteri.

2. Metode Penelitian

Alat dan Bahan

Alat-alat yang digunakan dalam penelitian ini yaitu autoklaf (hirayama hve-50 autoclave), api bunsen, batang pengaduk, cawan petri ((Duran Wheaton Kimble), Erlenmeyer (Iwaki), gelas kimia (Pyrex), gelas ukur (Pyrex), gunting, inkubator (memmert in55 incubator), jangka sorong, jarum ose, maserator, oven (Shel lab), pipet mikro (Eppendorf), pipet tetes, pinset, tabung reaksi (Pyrex), timbangan analitik.

Bahan-bahan yang digunakan pada penelitian ini adalah Alkohol, Alumunium foil, Aquades, Kloramfenikol paper disk, Etil Asetat, $\mathrm{FeCl}_{3}, \mathrm{HCl} 2 \mathrm{~N}, \mathrm{HCl}$ pekat, $\mathrm{H}_{2} \mathrm{SO}_{4}$, Kapas, Kertas cakram, kloroform, korek api, metanol, $\mathrm{NaCl} \mathrm{0,9 \% ,} \mathrm{N-heksan,} \mathrm{nutrient} \mathrm{agar,} \mathrm{pereaksi} \mathrm{dragendorff,}$ reagen mayer, serbuk magnesium, tissue

Sampel tumbuhan yang digunakan pada penelitian ini adalah Jahe merah (Zingiber officinale var. rubrum.), Bakteri yang digunakan pada penelitian ini adalah Staphylococcus epidermidis, dan Escherchia coli yang diperoleh dari koleksi Laboratorium Mikrobiologi Farmasi, Fakultas Olahraga dan Kesehatan, Universitas Negeri Gorontalo.

Preprasi Sampel

Sampel yang diperoleh kemudian disortasi basah, setelah itu sampel daun jahe merah (Zingiber officinale var. rubrum.) dicuci menggunakan air yang mengalir hingga bersih dan ditiriskan.kemudian dilakukan perajangan setelah itu sampel yang telah dirajang di keringkan dan di blender hingga halus.

Pada penelitian ini dilakukan ekstraksi secara maserasi bertingkat menggunakan pelarut nheksan, etil asetat, kloroform dan metanol.Tahapan ekstraksi dibuat dengan merendam simplisia serbuk daun jahe merah (Zingiber officinale var. Rubrum.) ke dalam $1000 \mathrm{ml}$ n-heksan.Maserasi dilakukan selama 3 hari dan diaduk tiap 12 jam. Hasil maserasi ekstrak n-heksan disaring, filtrat yang diperoleh di pekatkan menggunakan alat evaporator hingga menjadi ekstrak kental dan residu yang dihasilkan diangin-anginkan kemudian di maserasi kembali dengan pelarut kloroform sebanyak $1000 \mathrm{ml}$. Maserasi dilakukan selama 3 hari dan diaduk sampai ekstraksi berlangsung sempurna. Hasil maserasi ekstrak kloroform disaring, filtrat yang diperoleh dipekatkan menggunakan alat evaporator hingga ekstrak menjadi kental dan residu yang dihasilkan diangin- 
anginkan kemudian di maserasi kembali menggunakan pelarut etil asetat sebanyak $1000 \mathrm{ml}$. Maserasi dilakukan selama 3 hari dan diaduk tiap 12 jam. Hasil maserasi ekstrak etil asetat disaring, filtrat yang diperoleh dipekatkan menggunakan alat evaporator hingga ekstrak menjadi kental dan residu yang dihasilkan diangin-anginkan kemudian di maserasi kembali menggunakan pelarut metanol sebanyak $1000 \mathrm{ml}$. Hasil maserasi ekstrak metanol disaring dan filtrat yang diperoleh di pekatkan menggunakan evaporator dalam suhu $45^{\circ} \mathrm{C}$ selama 48 jam. Masing-masing ekstrak yang telah dipekatkan ditimbang.

Persiapan dan Uji Aktivitas Antibakteri

Pembuatan suspensi bakteri dilakukan secara aseptis dengan cara koloni bakteri uji pada media peremajaan yang sudah diinkubasi 24 jam diambil dengan menggunakan jarum ose dan disuspensikan ke dalam tabung berisi $5 \mathrm{ml}$ larutan $\mathrm{NaCl}$ steril 0,9\%. Kekeruhan yang telah diperoleh kemudian disetarakan dengan standar McFarland 0,5\% [3].

Bakteri yang digunakan pada penelitian ini yaitu bakteri Staphylococcus epidermidis, dan Escherchia coli yang diperoleh dari laboratorium Mikrobiologi Farmasi Universitas Negeri Gorontalo. Inokulasi bakteri dilakukan dengan metode pour plate atau metode tuang. Sebelum digunakan, bakteri uji harus di regenerasi dari medium lama ke medium yang baru. Biakan bakteri yang akan dilakukan pengujiam ditanam satu ose pada $10 \mathrm{ml}$ media nutrient agar, setelah itu diinkubasi selama 48 jam. Setelah itu dari biakan tersebut diambil 0,1 ml dan dituang ke dalam $250 \mathrm{ml}$ media nutrient agar. Kemudian nutrient agar dituang pada cawan petri yang disetiap cawan berisi $20 \mathrm{ml}$ media nutrient agar [8]

Skrining Fitokimia

Dilakukan pengujian skrining fitokimia ekstrak jahe merah (Zingiber officinale var. rubrum.) meliputi uji Alkaloid, Triterpenoid, Steroid, Tanin, Flavonoid,dan Saponin.

Uji Potensi Antibakteri

Pengujian potensi antibakteri dilakukan menggunakan metode difusi, dengan menggunakan Paper disk. Tahapan pertama yaitu Paper disk yang berdiameter $0,5 \mathrm{~cm}$ diambil dengan cara yang aseptis serta menggunakan pinset yang sudah terlebih dahulu disterilisasi. Paper disk itu dimasukkan kedalam masing-masing konsentrasi ekstrak daun jahe merah (Zingiber officinale var. rubrum.) selama 1 jam, setelah itu diletakkan pada media yang berisi bakteri uji, kontrol negatif yang digunakan Dimetil Sulfoksida (DMSO) dan kloramfenikol paper disk sebagai kontrol positif. Perlakuan ini direplikasi sebanyak 2 kali. Media yang telah diberi perlakuan diinkubasi selama 24 jam dengan temperature $37^{\circ} \mathrm{C}$. Efektivitas antibakteri ekstrak daun jahe merah (Zingiber officinale var. rubrum.)dilihat dan diukur berdasarkan zona hambat yang diperoleh [11].

Analisis Data

Efektifitas yang berbeda secara signifikan dari tiap-tiap konsetrasi ekstrak daun jahe merah (Zingiber officinale var. rubrum.) ketika menghambat pertumbuhan Staphylococcus aureus, dan Escherchia coli dapat dilihat dengan perhitungan SPSS dengan cara menganalisis data menggunakan one-way ANOVA.

\section{Hasil Dan Pembahasan}

\section{Ekstraksi}

Tabel 1 menunjukkan hasil ekstrak menggunakan metode maserasi bertingkat dengan \% Rendamen masing-masing ekstrak daun jahe merah, dimana \% Rendamen untuk ekstrak N-Heksan dan Kloroform daun jahe merah (Zingiber officinale var. rubrum) adalah 7,53\% dan 6,71\% sedangkan \%Rendamen ekstrak Etil Asetat dan metanol daun jahe merah (Zingiber officinale var. rubrum) yaitu $8,62 \%$ dan $16,7 \%$ hal ini menunjukkan bahwa proses ekstraksi daun jahe merah berlangsung 
baik.Persentase rendamen dapat dikatakan sempurna jika hasilnya berkisar antara 10-15\%, karena semakin tinggi \% rendamen maka semakin banyak pula zat yang dikandung [12].

Tabel 1.Hasil Ekstraksi

\begin{tabular}{cccc}
\hline Berat sampel $\mathbf{( g )}$ & Pelarut & Ekstrak (g) & \%Rendamen \\
\hline 300 & N-Heksan & 22,8 & 7,53 \\
\hline 283 & Kloroform & 19 & 6,71 \\
\hline 232 & Etil Asetat & 20 & 8,62 \\
\hline
\end{tabular}

\section{Uji Skrining Fitokimia}

Tabel 2. Hasil skrining Fitokimia Ekstrak N-heksan daunjahe merah

\begin{tabular}{ccccc}
\hline No & $\begin{array}{c}\text { Golongan } \\
\text { Senyawa }\end{array}$ & Pereaksi & $\begin{array}{c}\text { Perubahan Dengan } \\
\text { Pereaksi }\end{array}$ & Keterangan \\
\hline 1 & Alkaloid & $\begin{array}{c}\text { Kloroform }+ \text { Amoniak }+\mathrm{H} 2 \mathrm{SO} 4+ \\
\text { Pereaksi Dragendroff }\end{array}$ & $\begin{array}{c}\text { Endapan merah } \\
\text { bata }\end{array}$ & $\begin{array}{c}\text { Positif } \\
\text { Alkaloid }\end{array}$ \\
\hline 2 & Terpenoid & Asetat Anhidrat $+\mathrm{H}_{2} \mathrm{SO}_{4}$ & $\begin{array}{c}\text { Coklat, memiliki } \\
\text { cincin }\end{array}$ & $\begin{array}{c}\text { Positif } \\
\text { Terpenoid }\end{array}$ \\
\hline 3 & Tanin & Aquades $+\mathrm{FeCl} 31 \%$ & Endapan kuning & Negatif Tanin \\
\hline 4 & Saponin & Aquadest & Tidak Berbusa & $\begin{array}{c}\text { Negatif } \\
\text { Saponin }\end{array}$ \\
\hline 5 & Flavonoid & Pita Magnesium $+\mathrm{HCl}$ & Endapan coklat & $\begin{array}{c}\text { Negatif } \\
\text { Flavonoid }\end{array}$ \\
\hline
\end{tabular}

Tabel 2 menunjukkan hasil skrining fitokimia Ekstrak daun jahe merah (Zingiber officinale var. rubrum), dimana ekstrak kental positif mengandung alkaloid dan terpenoid.

Tabel 3. Hasil skrining Fitokimia Ekstrak Kloroform daun jahe merah

\begin{tabular}{ccccc}
\hline No & $\begin{array}{c}\text { Golongan } \\
\text { Senyawa }\end{array}$ & Pereaksi & $\begin{array}{c}\text { Perubahan Dengan } \\
\text { Pereaksi }\end{array}$ & Keterangan \\
\hline 1 & Alkaloid & $\begin{array}{c}\text { Kloroform + Amoniak } \\
+\mathrm{H} 2 \mathrm{SO} 4+\text { Pereaksi } \\
\text { Dragendroff }\end{array}$ & Endapan merah bata & Positif Alkaloid \\
\hline 2 & Steroid & $\begin{array}{c}\text { Asetat Anhidrat }+ \\
\mathrm{H}_{2} \mathrm{SO}_{4}\end{array}$ & Hijau, memiliki cincin & $\begin{array}{c}\text { Positif } \\
\text { Terpenoid }\end{array}$ \\
\hline 3 & Tanin & Aquades $+\mathrm{FeCl} 31 \%$ & Hijau kehitaman & Positif Tanin \\
\hline 4 & Saponin & Aquadest & Tidak Berbusa & Negatif Saponin \\
\hline 5 & Flavonoid & Pita Magnesium + & Endapan coklat & Negatif \\
& & HCl & & Flavonoid \\
\hline
\end{tabular}

Tabel 3 menunjukkan hasil skrining fitokimia Ekstrak daun jahe merah (Zingiber officinale var. rubrum), dimana ekstrak kental positif mengandung Alkaloid, Steroid, dan Tanin.

Tabel 4. Hasil skrining Fitokimia Ekstrak Etil asetat daun jahe merah

\begin{tabular}{ccccc}
\hline No & $\begin{array}{c}\text { Golongan } \\
\text { Senyawa }\end{array}$ & Pereaksi & $\begin{array}{c}\text { Perubahan Dengan } \\
\text { Pereaksi }\end{array}$ & Keterangan \\
& & \\
\hline
\end{tabular}




\begin{tabular}{ccccc}
\hline 1 & Alkaloid & $\begin{array}{c}\text { Kloroform + Amoniak } \\
+\mathrm{H} 2 \mathrm{SO} 4+\text { Pereaksi } \\
\text { Dragendroff }\end{array}$ & Endapan merah bata & Positif Alkaloid \\
\hline 2 & Steroid & $\begin{array}{c}\text { Asetat Anhidrat }+ \\
\mathrm{H}_{2} \mathrm{SO}_{4}\end{array}$ & Hijau, memiliki cincin & $\begin{array}{c}\text { Positif } \\
\text { Terpenoid }\end{array}$ \\
\hline 3 & Tanin & Aquades $+\mathrm{FeCl} 31 \%$ & Hijau kehitaman & Positif Tanin \\
\hline 4 & Saponin & Aquadest & Tidak Berbusa & Negatif Saponin \\
\hline 5 & Flavonoid & Pita Magnesium + & Ungu, memiliki cincin & PositifFlavonoid \\
& & HCl & & \\
\hline
\end{tabular}

Tabel 4 menunjukkan hasil skrining fitokimia Ekstrak daun jahe merah (Zingiber officinale var. rubrum), dimana ekstrak kental positif mengandung Alkaloid, steroid, Tanin, dan Flavonoid.

Tabel 5. Hasil skrining Fitokimia EkstrakMetanol daun jahe merah

\begin{tabular}{ccccc}
\hline No & $\begin{array}{c}\text { Golongan } \\
\text { Senyawa }\end{array}$ & Pereaksi & $\begin{array}{c}\text { Perubahan Dengan } \\
\text { Pereaksi }\end{array}$ & Keterangan \\
\hline 1 & Alkaloid & $\begin{array}{c}\text { Kloroform + Amoniak } \\
+\mathrm{H} 2 \mathrm{SO} 4+\text { Pereaksi } \\
\text { Dragendroff }\end{array}$ & Endapan merah bata & Positif Alkaloid \\
\hline 2 & Terpenoid & $\begin{array}{c}\text { Asetat Anhidrat }+ \\
\mathrm{H}_{2} \mathrm{SO}_{4}\end{array}$ & Ungu, memiliki cincin & $\begin{array}{c}\text { Positif } \\
\text { Terpenoid }\end{array}$ \\
\hline 3 & Tanin & Aquades $+\mathrm{FeCl3} \mathrm{1 \%}$ & Hijau kehitaman & Positif Tanin \\
\hline 4 & Saponin & Aquadest & Tidak Berbusa & Negatif Saponin \\
\hline 5 & Flavonoid & Pita Magnesium + & Endapan coklat & Negatif \\
& & HCl & & Flavonoid \\
\hline
\end{tabular}

Tabel 5 menunjukkan hasil skrining fitokimia Ekstrak daun jahe merah (Zingiber officinale var. rubrum), dimana ekstrak kental positif mengandung Alkaloid, Terpenoid, Tanin dan Flavonoid. Dari keempat ekstrak daun jahe merah didapatkan hasil skrining fitokimia yaitu pada Alkaloid digunakan kloroform, amoniak, $\mathrm{H} 2 \mathrm{SO} 4$ dan pereaksi dragendroff sebagai larutan uji.Prinsip dari identifikasi alkaloid yaitu terbentuknya endapan merah dari penambahan pereaksi terakhir yaitu dragendroff.Hasil uji skrining fitokimia menunjukkan bahwa sampel Ekstrak $\mathrm{n}$ heksan, Kloroform, Etil Asetat dan metanol Daun jahe merah (Zingiber officinale var. rubrum) positif mengandung alkaloid.Hal ini dibuktikan dengan terbentuknya endapan merah bata pada tabung reaksi setelah ditetesi reagen dragendroff [7].

Hasil uji skrining fitokimia Pada Saponinmenunjukkan bahwa sampel Ekstrak Ekstrak n heksan, Kloroform, Etil Asetat dan metanol Daun jahe merah (Zingiber officinale var. rubrum) tidak menunjukkan hasil positif karena tidak terdapat busa yang lama setelah ditambahkan aquades dan dikocok [10][15]. Sedangkan untuk Steroid dan Terpenoid Pada uji Steroid dan Terpenoid digunakan pereaksi asetat anhidrat dan $\mathrm{H} 2 \mathrm{SO} 4$. Hasil Uji skrining fitokimia menunjukan bahwa sampel sampel Ekstrak N-heksan Daun jahe merah (Zingiber officinale var. rubrum) mengandung Terpenoid ditandai dengan adanya perubahan berwarna Ungu pada sampel, sedangkan untuk Ekstral Kloroform dan Etil asetat Daun jahe merah (Zingiber officinale var. rubrum) mengandung steroid ditandai dengan adanya perubahan warna hijau pada sampel [7].

Pada uji tanin digunakan pereaksi aquades dan $\mathrm{FeCl} 3$. Hasil Uji skrining fitokimia menunjukan bahwa sampel sampel Ekstrak Kloroform, Etil asetat dan metanol Daun jahe merah (Zingiber officinale var. rubrum) positif mengandung tanin ditandai dengan terbentuknya warna hijau kehitaman setelah pengocokan. Sedangkan Ekstrak sampel Ekstrak N-heksan Daun jahe merah 
(Zingiber officinale var. rubrum) negatif mengandung tanin karena terbentuknya endapan kuning pada sampel [7].Sedangkan Pada uji flavonoid digunakan pita magnesium dan $\mathrm{HCl}$. Hasil skrining fitokimia menunjukan bahwa sampel Ekstrak Etil Asetat, dan Metanol Daun jahe merah (Zingiber officinale var. rubrum) positif mengandung flavonoid ditandai dengan adanya Karena terbentuknya cincin ungu pada sampel. Sedangkan sampel Ekstrak N-heksan, dan Kloroform Daun jahe merah (Zingiber officinale var. rubrum) negatif mengandung flavanoid sebab tidak terbentuknya cincin ungu pada sampel, melainkan berwarna hijau kekuningan [13].

Hasil Uji Daya hambat Antibakteri

Tabel 6.Hasil uji daya hambarantibakteri ekstrak n-heksan jahe merah terhadap s.epidermis

\begin{tabular}{lllll}
\hline Sampel & \multicolumn{2}{c}{$\begin{array}{c}\text { Diameter Zona Hambat } \\
(\mathbf{m m})\end{array}$} & Rata-rata $(\mathbf{m m})$ & Kategori \\
\hline Ekstrak 10\% & 11,42 & 10,65 & 11,03 & Kuat $^{* * *}$ \\
Ekstrak 15\% & 15,37 & 15,11 & 15,24 & Kuat $^{* * *}$ \\
Ekstrak 20\% & 18,47 & 17,5 & 17,98 & Kuat $^{* * *}$ \\
Kontrol (+) & 24,50 & 24,75 & 24,62 & Sangat Kuat $^{* * * *}$ \\
Kontrol (-) & 0 & 0 & $0 \pm 0$ & Tidak menghambat \\
\hline
\end{tabular}

Tabel 7.Hasil uji daya hambat antibakteri ekstrak n-heksan jahe merah terhadap e.coli

\begin{tabular}{lllll}
\hline Sampel & \multicolumn{2}{c}{$\begin{array}{c}\text { Diameter Zona Hambat } \\
(\mathbf{m m})\end{array}$} & Rata-rata $(\mathbf{m m})$ & Kategori \\
\hline Ekstrak 10\% & 9,34 & 8,89 & 9,11 & Sedang $^{* *}$ \\
Ekstrak 15\% & 15,2 & 14,27 & 14,73 & Kuat $^{* * *}$ \\
Ekstrak 20\% & 18,55 & 17,14 & 17,84 & Kuat $^{* * *}$ \\
Kontrol $(+)$ & 27,15 & 27,34 & 27,24 & Sangat Kuat $^{* * * *}$ \\
\hline
\end{tabular}

Tabel 8.Hasil Uji daya hambat antibakteri ekstrak kloroform jahe merah terhadap s.epidermis

\begin{tabular}{lllll}
\hline Sampel & \multicolumn{2}{c}{$\begin{array}{c}\text { Diameter Zona Hambat } \\
(\mathbf{m m})\end{array}$} & Rata-rata $(\mathbf{m m})$ & Kategori \\
\hline Ekstrak 10\% & 8,25 & 8,12 & 8,18 & Sedang $^{* * *}$ \\
Ekstrak 15\% & 16,2 & 15,63 & 15,91 & Kuat $^{* * *}$ \\
Ekstrak 20\% & 19,25 & 18,56 & 18,90 & Kuat $^{* * *}$ \\
Kontrol (+) & 24,50 & 24,75 & 24,62 & Sangat Kuat $^{* * * *}$ \\
Kontrol (-) & 0 & 0 & $0 \pm 0$ & Tidak menghambat $^{*}$ \\
\hline
\end{tabular}

\begin{tabular}{llcll}
\hline \multicolumn{2}{c}{ Tabel 9.Hasil uji daya hambat antibakteri ekstrak kloroform jahe merah terhadap e.coli } \\
\hline Sampel & $\begin{array}{c}\text { Diameter Zona Hambat } \\
(\mathbf{m m})\end{array}$ & Rata-rata $\mathbf{( m m )}$ & Kategori \\
\hline Ekstrak 10\% & 8,2 & 7,40 & 7,8 & sedang $^{* *}$ \\
Ekstrak 15\% & 10,27 & 10,11 & 10,19 & Kuat $^{* * *}$ \\
Ekstrak 20\% & 15,35 & 14,56 & 14,95 & Kuat $^{* * *}$ \\
Kontrol (+) & 27,15 & 27,34 & 27,24 & Sangat Kuat $^{* \star * *}$ \\
Kontrol (-) & 0 & 0 & $0 \pm 0$ & Tidak menghambat \\
\hline
\end{tabular}

\begin{tabular}{llcll}
\hline \multicolumn{2}{c}{ Tabel 10.Hasil uji daya hambat antibakteri ekstrak etil asetat jahe merah terhadap s.epidermis } \\
\hline Sampel & \multicolumn{2}{c}{$\begin{array}{c}\text { Diameter Zona Hambat } \\
(\mathbf{m m})\end{array}$} & Rata-rata $\mathbf{( m m )}$ & Kategori \\
\hline Ekstrak $10 \%$ & 10,42 & 11.75 & 11,08 & Kuat $^{* * *}$ \\
Ekstrak $15 \%$ & 15,4 & 14,45 & 14,92 & Kuat $^{* * *}$ \\
Ekstrak $20 \%$ & 18,40 & 17,78 & 18,09 & Kuat $^{* * *}$ \\
Kontrol $(+)$ & 24,50 & 24,75 & 24,62 & Sangat Kuat $^{* * * *}$ \\
\hline
\end{tabular}




\begin{tabular}{|c|c|c|c|c|}
\hline Kontrol (-) & 0 & 0 & $0 \pm 0$ & Tidak menghambat \\
\hline \multicolumn{5}{|c|}{ Tabel 11.Hasil uji daya hambat antibakteri ekstrak etil asetat jahe merah terhadap e.coli } \\
\hline Sampel & \multicolumn{2}{|c|}{$\begin{array}{l}\text { Diameter Zona Hambat } \\
(\mathrm{mm})\end{array}$} & Rata-rata (mm) & Kategori \\
\hline Ekstrak 10\% & 7,15 & 7,24 & 7,19 & Sedang $^{* *}$ \\
\hline Ekstrak 15\% & 10,37 & 10,29 & 10,29 & Kuat $^{* * *}$ \\
\hline Ekstrak 20\% & 15,45 & 15,22 & 15,33 & Kuat $^{* * *}$ \\
\hline Kontrol (+) & 27,15 & 27,34 & 27,24 & Sangat Kuat ${ }^{* * * *}$ \\
\hline Kontrol (-) & 0 & 0 & $0 \pm 0$ & Tidak menghambat \\
\hline \multicolumn{5}{|c|}{ Tabel 12.Hasil uji daya hambat antibakteri ekstrak metanol jahe merah terhadap s.epidermis } \\
\hline Sampel & \multicolumn{2}{|c|}{$\begin{array}{c}\text { Diameter Zona Hambat } \\
(\mathrm{mm})\end{array}$} & Rata-rata (mm) & Kategori \\
\hline Ekstrak 10\% & 10,35 & 9,10 & 9,72 & Sedang $^{* *}$ \\
\hline Ekstrak 15\% & 14,8 & 13,46 & 14,13 & Kuat $^{* * *}$ \\
\hline Ekstrak 20\% & 18,15 & 17,78 & 17,96 & Kuat $^{\star \star *}$ \\
\hline Kontrol (+) & 24,50 & 24,75 & 24,62 & Sangat Kuat ${ }^{* * *}$ \\
\hline Kontrol (-) & 0 & 0 & $0 \pm 0$ & Tidak menghambat \\
\hline \multicolumn{5}{|c|}{ Tabel 13.Hasil uji daya hambat antibakteri ekstrak metanol jahe merah terhadap e.coli } \\
\hline Sampel & \multicolumn{2}{|c|}{$\begin{array}{c}\text { Diameter Zona Hambat } \\
(\mathrm{mm})\end{array}$} & Rata-rata $(\mathrm{mm})$ & Kategori \\
\hline Ekstrak 10\% & 9,55 & 9,11 & 9,33 & Sedang $^{* *}$ \\
\hline Ekstrak 15\% & 13,48 & 13,10 & 13,29 & Kuat $^{* \star *}$ \\
\hline Ekstrak 20\% & 17,32 & 16,98 & 17,15 & $\mathrm{Kuat}^{* * *}$ \\
\hline Kontrol (+) & 27,15 & 27,34 & 27,24 & Sangat Kuat ${ }^{\star \star * * *}$ \\
\hline Kontrol (-) & 0 & 0 & $0 \pm 0$ & Tidak menghambat \\
\hline
\end{tabular}




\section{Hasil uji daya hambat}

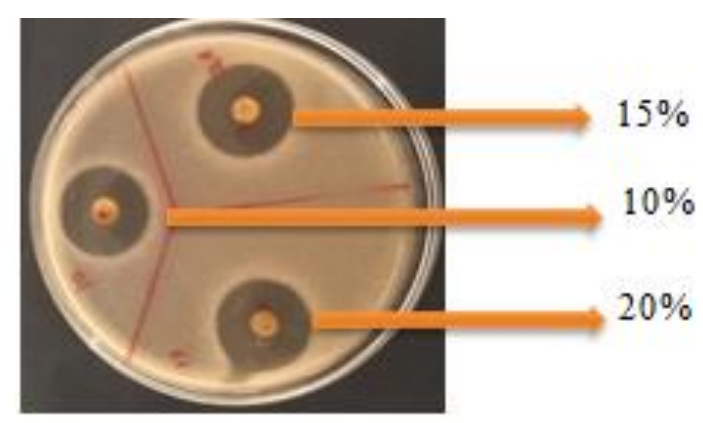

Gambar 1. Daya Hambat Ekstrak N heksan Daun Jahe merah terhadap Staphylococcus Epidermidis dengan Konsentrasi $10 \%$, 15\% dan $20 \%$

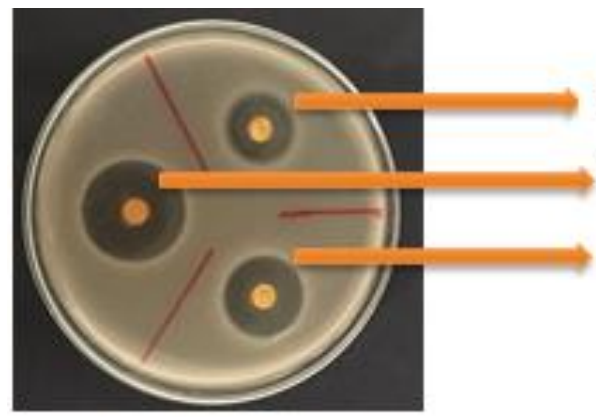

$10 \%$

$20 \%$

$15 \%$

Gambar 3. Daya Hambat Ekstrak Kloroform Daun Jahe merah terhadap Staphylococcus Epidermidis dengan Konsentrasi 10\%, 15\% dan 20\%

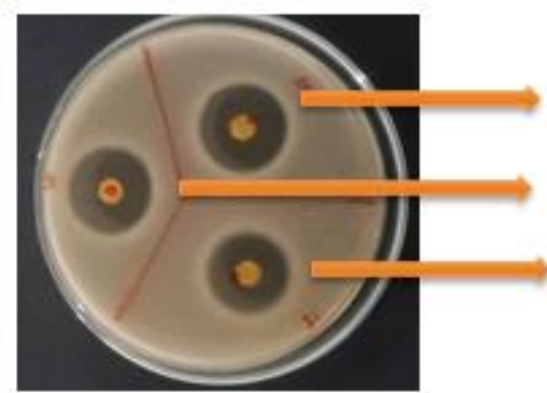

$10 \%$

$20 \%$

$15 \%$

Gambar 5. Daya Hambat Ekstrak Etil asetat Daun Jahe merah terhadap Staphylococcus Epidermidis dengan Konsentrasi 10\%, 15\% dan $20 \%$

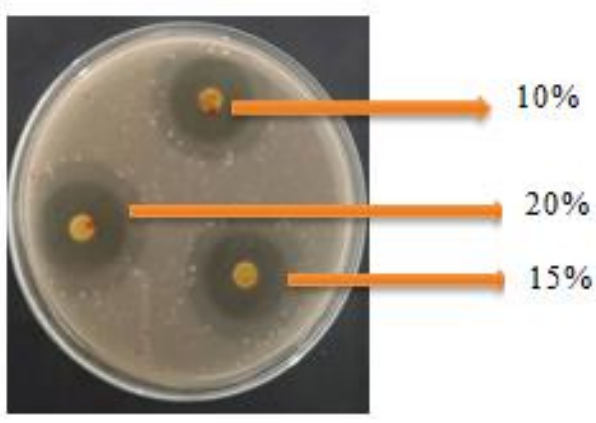

Gambar 2. Daya Hambat Ekstrak N heksan Daun Jahe merah terhadap Escherichia coli dengan Konsentrasi 10\%, $15 \%$ dan $20 \%$

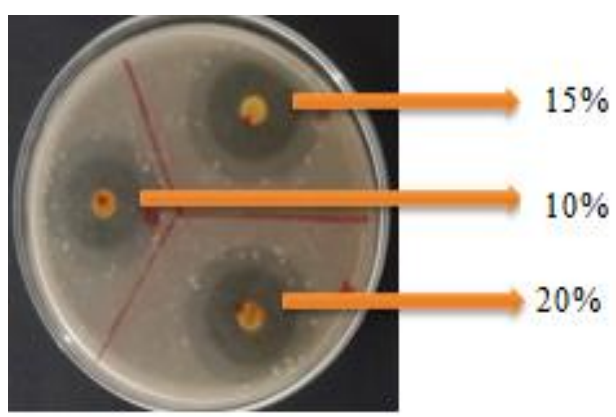

Gambar 4. Daya Hambat Ekstrak Kloroform Daun Jahe merah terhadap Escherichia coli dengan Konsentrasi 10\%, 15\% dan 20\%

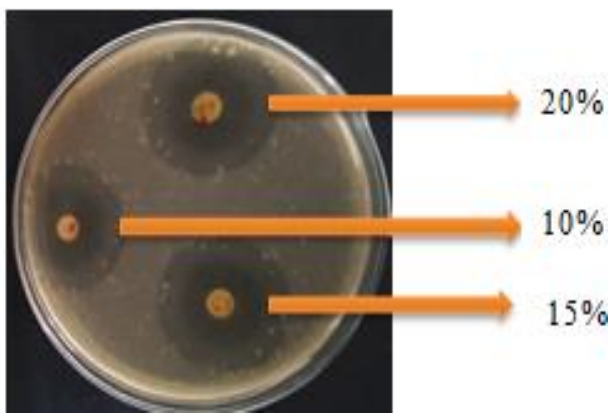

Gambar 6. Daya Hambat Ekstrak Etil asetat Daun Jahe merah terhadap

Escherichia coli dengan Konsentrasi 10\%, $15 \%$ dan $20 \%$ 


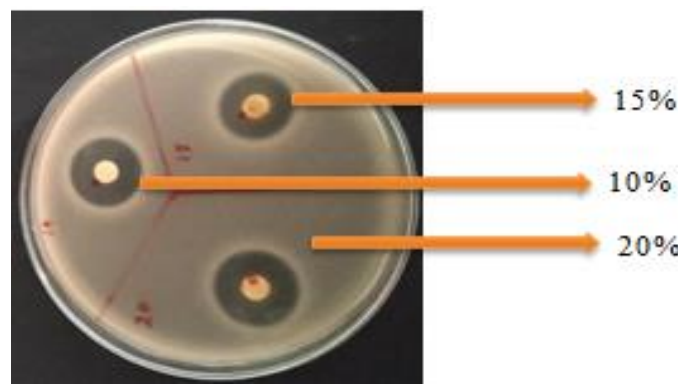

Gambar 7. Daya Hambat Ekstrak

Metanol Daun Jahe merah terhadap

Staphylococcus Epidermidis dengan

Konsentrasi $10 \%$, 15\% dan $20 \%$

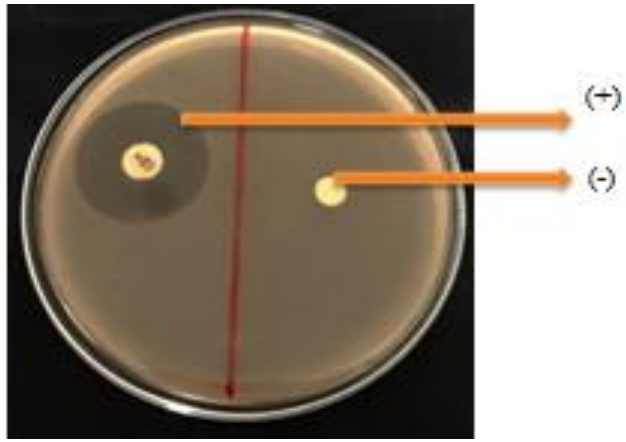

Gambar 9. Daya Hambat Kontrol Positif

Dan Kontrol Negatif Staphylococcus Epidermidis

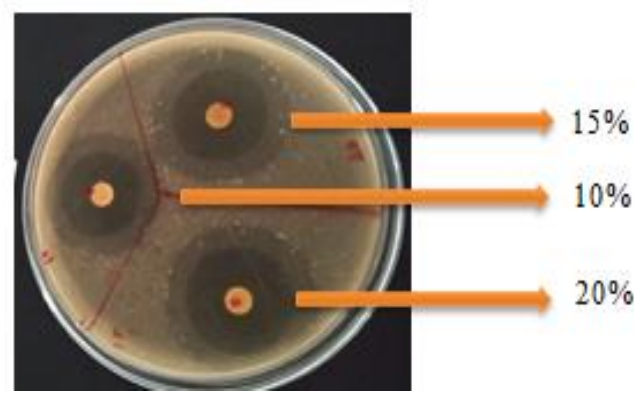

Gambar 8. Daya Hambat Ekstrak Metanol Daun Jahe merah terhadap Escherichia coli dengan Konsentrasi $10 \%, 15 \%$ dan $20 \%$

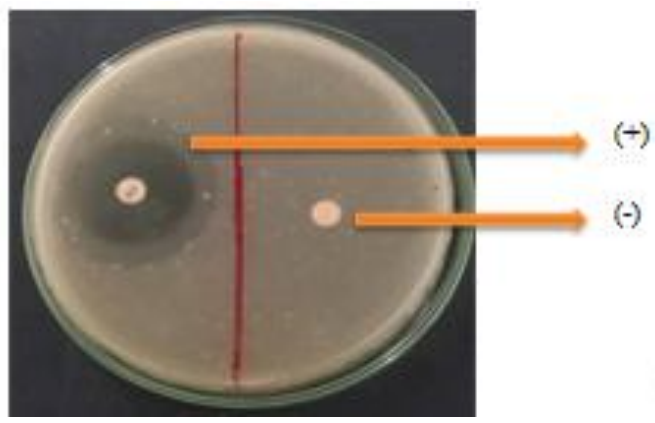

Gambar 10. Daya Hambat Kontrol Positif Dan Kontrol Negatif Escherichia coli

Ekstrak yang pertama yaitu pada ekstrak $n$ heksan yaitu pada tabel 6.Hasil uji aktivitas hambatan pertumbuhan bakteri Staphylococcus epidermidis pada ekstrak n-heksan menunjukkan bahwa ekstrak ini mampu menghambat pertumbuhan bakteri dibuktikan dengan terbentuknya zona bening disekitar kertas cakram. Berdasarkan tabel 6 terlihat bahwa hambatan terkecil diperoleh pada konsentrasi $10 \%$ dimana zona hambat yang dihasilkan $11,03 \mathrm{~mm}$, sedangkan zona hambat terbesar dihasilkan oleh konsentrasi ekstrak yaitu $20 \%$ dengan zona hambat yang dihasilkan 17,98 mm. Hasil uji zona hambat ekstrak n-heksan terhadap pertumbuhan bakteri Escherichia coli menunjukkan bahwa ekstrak mampu menghambat pertumbuhan bakteri ini dibuktikan dengan adanya zona bening disekitar kertas cakram. Berdasarkan tabel 7 hambatan terkecil yang dihasilkan yaitu pada konsentrasi 10\% dengan zona hambat 9,11 mm, sedangkan zona hambat terbesar dihasilkan oleh konsentrasi ekstrak $20 \%$ dengan zona hambat yang dihasilkan 17,84 mm.

Hasil uji aktivitas hambatan pertumbuhan bakteri Staphylococcus epidermidis pada ekstrak yang kedua yaitu ekstrak kloroform daun jahe merah (Zingiber officinale var. rubrum) menunjukkan bahwa ekstrak ini mampu menghambat pertumbuhan bakteri dibuktikan dengan terbentuknya zona bening disekitar kertas cakram. Berdasarkan tabel 8 terlihat diperoleh pada konsentrasi 10\% dimana zona hambat yang dihasilkan $8,18 \mathrm{~mm}$, sedangkan zona hambat terbesar dihasilkan oleh konsentrasi ekstrak yaitu 20\% dengan zona hambat yang dihasilkan 18,90 mm. Hasil uji zona hambat ekstrak 
kloroform terhadap pertumbuhan bakteri Escherichia coli menunjukkan bahwa ekstrak mampu menghambat pertumbuhan bakteri ini dibuktikan dengan adanya zona bening disekitar kertas cakram. Berdasarkan tabel 9 hambatan terkecil yang dihasilkan yaitu pada konsentrasi $10 \%$ dengan zona hambat $7,8 \mathrm{~mm}$, sedangkan zona hambat terbesar dihasilkan oleh konsentrasi ekstrak $20 \%$ dengan zona hambat yang dihasilkan $14,95 \mathrm{~mm}$.

Hasil uji aktivitas hambatan pertumbuhan bakteri Staphylococcus epidermidis pada ekstrak Ketiga ekstrak etil asetat daun jahe merah (Zingiber officinale var. rubrum) menunjukkan bahwa ekstrak ini mampu menghambat pertumbuhan bakteri dibuktikan dengan terbentuknya zona bening disekitar kertas cakram. Berdasarkan tabel 10 terlihat bahwa hambatan terkecil diperoleh pada konsentrasi $10 \%$ dimana zona hambat yang dihasilkan $11,08 \mathrm{~mm}$, sedangkan zona hambat terbesar dihasilkan oleh konsentrasi ekstrak yaitu 20\% dengan zona hambat yang dihasilkan 18,09 mm. Hasil uji zona hambat ekstrak etil asetat terhadap pertumbuhan bakteri Escherichia coli menunjukkan bahwa ekstrak mampu menghambat pertumbuhan bakteri ini dibuktikan dengan adanya zona bening disekitar kertas cakram. Berdasarkan tabel 11 hambatan terkecil yang dihasilkan yaitu pada konsentrasi $10 \%$ dengan zona hambat 7,19 mm, sedangkan zona hambat terbesar dihasilkan oleh konsentrasi ekstrak $20 \%$ dengan zona hambat yang dihasilkan $15,33 \mathrm{~mm}$.

Hasil uji aktivitas hambatan pertumbuhan bakteri Staphylococcus epidermidis pada ekstrak keempat ekstrak metanol daun jahe merah (Zingiber officinale var. rubrum) menunjukkan bahwa ekstrak ini mampu menghambat pertumbuhan bakteri dibuktikan dengan terbentuknya zona bening disekitar kertas cakram. Berdasarkan tabel 12 terlihat bahwa hambatan terkecil diperoleh pada konsentrasi 10\% dimana zona hambat yang dihasilkan 9,72 mm, sedangkan zona hambat terbesar dihasilkan oleh konsentrasi ekstrak yaitu $20 \%$ dengan zona hambat yang dihasilkan 17,96 mm. Hasil uji zona hambat ekstrak Metanol terhadap pertumbuhan bakteri Escherichia coli menunjukkan bahwa ekstrak mampu menghambat pertumbuhan bakteri ini dibuktikan dengan adanya zona bening disekitar kertas cakram. Berdasarkan tabel 13 hambatan terkecil yang dihasilkan yaitu pada konsentrasi $10 \%$ dengan zona hambat $9,33 \mathrm{~mm}$, sedangkan zona hambat terbesar dihasilkan oleh konsentrasi ekstrak 20\% dengan zona hambat yang dihasilkan 17,15 mm.Zona hambat yang terbentuk yang dihasilkan menggunakan metode diffusi agar yaitu berukuran kurang dari $5 \mathrm{~mm}$ maka dikategorikan lemah, apabila ukuran zona hambat 5-10 mm dikategorikan sedang atau cukup menghambat, 10-19 mm dikategorikan kuat menghambat dan jika ukuran zona hambat 20 hingga lebih dari $20 \mathrm{~mm}$ maka dikategorikan sangat kuat [16].

\section{Analisis Data}

Berdasarkan analisis statistik, konsentrasi ekstrak n-heksan, kloroform, etil asetat dan metanol daun jahe merah (Zingiber officinale var. rubrum) berpengaruh terhadap diameter zona hambat pertumbuhan bakteri Staphylococcus epidermidis dan Escherichia coli. Hasil analisis anova, menghasilkan nilai signifikan kurang dari 0,01 artinya terdapat perbedaan yang signifikan terhadap daya hambat pada ekstrak 10\%, 15\% dan 20\% dimana ekstrak 10\% dinilai cukup baik dalam menghambat pertumbuhan bakteri Staphylococcus epidermidis dan Escherichia coli.

\section{Kesimpulan}

Berdasarkan hasil penelitian yang telah dilakukan diperoleh bahwa senyawa metabolit sekunder yang terkandung dalam ekstrak n-heksan yaitu alkaloid dan terpenoid, pada ekstrak kloroform terdapat alkaloid, tanin dan steroid ,sedangkan pada ekstrak etil asetat terdapat senyawa alkaloid, flavonoid, tanin dan steroid. Dan pada ekstrak metanol mengandung senyawa Alkaloid, Flavonoid, Tanin dan Terpenoid. Ekstrak n-heksan, kloroform, etil asetat dan metanol daun jahe merah (Zingiber officinale var. rubrum) mempunyai potensi sebagai antibakteri. Konsentrasi ekstrak berbeda secara signifikan dalam menghambat pertumbuhan bakteri, dari keempat ekstrak n-heksan, 
ekstrak kloroform, ekstrak etil asetat, dan ekstrak metanol dengan tiga konsentrasi yang berbeda di dapatkan hasil daya hambat yang paling besar terhadap bakteri Staphylococcus Epidermidis yaitu pada konsentrasi $20 \%$ ekstrak klorform daun jahe merah sebesar 18,90 mm. Sedangkan untuk daya hambat terhadap Escherichia Coli yaitu pada konsentrasi 20 \% esktrak n-heksan dengan daya hambat sebesar $17,84 \mathrm{~mm}$.

Referensi:

[1] Ali, B., Al-Wabel, N.A., Shams, S., Ahamad, A., Khan, S.A. and Anwar, F., 2015. Essential Oils Used in Aromatherapy: A Systemic Review. Asian Pacific Journal of Tropical Biomedicine. 5, Pp.601-611

[2] Arna Ningsih dan Arsyik Ibrahim. 2013. Aktifitas antimikroba ekstrak fraksi n-heksan daun sungkai (peronema canescens. Jack) terhadap beberapa bakteri dengan metode klt-bioautografi. Universitas mulawarman: samarinda

[3] Aziz Syaikhul., 2010, Uji Aktivitas Antibakteri Ekstrak Etanol Daun dan Umbi Bakung Putih (Crinum asiaticum L.) Terhadap Bakteri Penyebab Jerawat,Skripsi, Fakultas Kedokteran dan Ilmu Kesehatan Universitas IslamNegeri Syarif Hidayatullah, Jakarta

[4] Brooks, G. F., Carroll, K. C., Butel, J. S., Morse, S. A., Mietzner, T. 2013. Jawetz, Melnick, E Adelberg's Medical Microbiology, 26th Edition. McGraw-Hill: New York

[5] Kamazeri, T.S., Samah, O.A., Taher, M., Susanti, D. and Qaralleh, H. 2012. Antimicrobial Activity and Essential Oils of Curcuma aeruginosa, Curcuma mangga, and Zingiber cassumunar from Malaysia. Asian Pacific Journal of Tropical Medicine , 5, Pp.202-209.

[6] Kholipatus syuhada. 2017. Evaluasi penambahan ekstrak daun jahe merah (zingiber officinale var. Rubrum) terhadap aktivitas antioksidan, total bakteri, ph, dan sifat organoleptik susu pasteurisasi komersial. Universitas dipenogoro : semarang

[7] Harbone, J.B., Phytochemical Methods, diterjemahkan oleh Kosasi Padmawinata dan Iwang Soedio. 1987. Metode Fitokimia: Penuntun Cara Modern Menganalisis Tumbuhan. Penerbit ITB : Bandung.

[8] Lay, B. W. and Hastowo. 1992. Mikrobiologi. Jakarta: Rajawali Press

[9] Mesomo, M.C., Corazza, M.L., Ndiaye, P.M., Dalla Santa, O.R., Cardozo, L. And Scheer, A.P. 2013. Supercritical CO2Extracts and Essential Oil of Ginger (Zingiber officinale R.): Chemical Composition and Antibacterial

[10] Mojab, F., Kamalinejad, M., Ghadeni, N., dan Vahidipour, H. R. 2003. Phytocemical Screening of Some Species of Iranian Plants.Iranian Journal of Pharmaceutical Research.

[11] Pratiwi, Sylvia T. 2008. Mikrobiologi Farmasi. Jakarta: Erlangga.

[12] Putri, R.R., R.F. Hakim, dan S. Rezeki. 2017. Pengaruh Ekstrak Daun Tapak Dara (Catharanthus roseus) terhadap Jumlah Fibroblas pada Proses Penyembuhan Luka di Mukosa Oral. Journal Caninus Denstistry

[13] Ratna Djamil, Dkk. 2014, Identifikasi Senyawa Flavonoid Ekstrak Metanol Herba Jombang, Taraxacum Officinale Wiggers. ( ASTERACEAE) Secara Spektrofotometri Ultraviolet-Visibel. Fakultas Farmasi Universitas Pancasila : Jakarta

[14] Shandar, H.K., B. Kumar, S. Prasher, P. Tiwari, M. Salhan, \& P. Sharma. 2011. A Review Of Phytochemistry And Pharmacology Of Flavonoids. Internationale Pharmaceutica Sciencia, Vol. 1

[15] Sarma, D. S. K \& Babu, A. V. S. 2011. Antioxidant and Antimicrobial Activity of Ocimum americanum. PHARMANEST - An International Journal of Advances In Pharmaceutical Sciences Vol.2. ISSN 0976 -3090

[16] Sivasothy, Y., Chong, W.K., Hamid, A., Eldeen, I.M., Sulaiman, S.F. and Awang, K. 2011. Essential Oils of Zingiber officinale var. Rubrum Theilade and Their Antibacterial Activities. Food Chemistry. 124, Pp. 514-517. 
Ibrahim et al., 2021; Indonesian Journal of Pharmacetical Education (e-Journal); 1(3): 107-118 